\title{
Competence of planning educational process in pre-service teacher training 1
}

\begin{abstract}
Currently, the Slovak system of education requires an increase in its quality, which is influenced by quality of teacher training. Pre-service education of teachers must respond to current requirements concerning their professional competences. Management and planning of education are one of the fundamental teaching skills for teacher's successful integration in school. The issue is a part of a research project Assessment of Teacher's Competences (APVV-14-0446).

Planning is an initial activity and a part of the management of educational work. It is a complicated process that a teacher implements at several levels. The paper focuses on the analysis of the nature and components of the competence to plan the teaching process. It presents the results of empirical research carried out with students at the master's level of their studies at the Faculty of Arts, Constantine the Philosopher University in Nitra.

The need for high-quality pre-service education of teachers requires strengthening their educational needs at the cognitive level. The theoretical aspect and knowledge of the nature and importance of the analyzed competence requires a direct link with practical training of students. The formation and development of future teacher's professionalism assumes development of their teaching skills which are supported by various modules of teaching experience during their university studies. In the context of developing the competence to plan the teaching process, the ability to create a model lesson is considered to be the basic teaching skill based on the ability of the relevant choice of subject matter, teaching and learning activities to ensure achievement of the set goals by students.
\end{abstract}

Keywords: teacher, competence, planning the educational process, pre-service studies.

\footnotetext{
* Constantine the Philosopher University in Nitra, Slovakia.

** Constantine the Philosopher University in Nitra, Slovakia.

1 This work was supported by the Slovak Research and Development Agency under the contract $\mathrm{N}^{\circ}$ APVV-14-0446.
} 


\title{
Kompetencje planowania procesu edukacyjnego w kształceniu przyszłych nauczycieli
}

\begin{abstract}
Abstrakt
Słowacki system edukacji wymaga troski o wysoką jakość, która zależna jest od poziomu kształcenia nauczycieli. Przygotowanie zawodowe nauczycieli musi odpowiadać bieżącym oczekiwaniom w zakresie ich kompetencji zawodowych. Zarządzanie i planowanie procesu kształcenia jest jedną z podstawowych umiejętności planowania pracy nauczyciela w szkole. Kwestia ta jest częścią projektu badawczego „Ocena kompetencji nauczyciela" (APVV-14-0446).

Planowanie jest początkową czynnością i elementem zarządzania edukacją. Jest to skomplikowany proces, który jest wdrażany przez nauczycieli na kilku poziomach. Artykuł koncentruje się na analizie istoty i składników kompetencji niezbędnych do planowania procesu dydaktycznego. Przedstawiono w nim wyniki badań empirycznych przeprowadzonych ze studentami na poziomie studiów magisterskich na Wydziale Sztuki na Uniwersytecie Konstantego Filozofa w Nitrze.

Potrzeba wysokiej jakości kształcenia nauczycieli zanim podejmą pracę zawodową wymaga przygotowania merytorycznego. Aspekt teoretyczny oraz znajomość charakteru i znaczenia związanej z tym kompetencji poznawczej (kognitywnej) wymaga bezpośredniego powiązania jej z praktycznym kształceniem studentów. Formacja i rozwój profesjonalizmu przyszłego nauczyciela zakłada rozwój jego/jej umiejętności nauczania, które są wspierane przez różne moduły doświadczenia pedagogicznego podczas studiów uniwersyteckich.

W kontekście rozwijania kompetencji planowania procesu nauczania, umiejętność tworzenia modelowej lekcji jest uważana za podstawową umiejętność w kształceniu innych, która bazuje na odpowiednim wyborze tematu. Zadania dydaktyczne i edukacyjne powinny zapewniać osiągnięcie wyznaczonych celów przez uczniów.
\end{abstract}

Słowa kluczowe: nauczyciel, kompetencje, planowanie procesu edukacyjnego, kształcenie przyszłych nauczycieli.

\section{Introduction}

Successful implementation of the teaching process presupposes a systematic and effective approach to the use of the time available to the teacher during the teaching process within which they concentrate on the development of the pupil's personality, skills and knowledge. The determination of ways and approaches to teacher's work is currently the subject of a discussion among Slovak experts (Pavlov 2013, Kosová 2011) who agree that the basic source of success in educating and upbringing the young generation is the availability of professional competences of teachers. The set of teacher's competences (Šnídlová 2011, Predanocyová 2016) includes all relevant areas and aspects of the educational process and consists of specific knowledge, skills and abilities. We consider planning as one of the key 
competences which is the starting point for the organization and management of education. In its creation and development it is necessary to take into account its process specificity and its interrelatedness to the complex of other pedagogical skills.

The paper points out a decrease in the current state of quality of education in Slovakia and the search for resources from this situation in the form of a new approach to education designed by the state as well as the solutions developed within the research project of the team of experts from the Constantine the Philosopher University in Nitra. The central topic is the planning of education as a teacher's competence to be developed in the context of pre-service training. The paper presents a theoretical analysis of planning the components as well as the ways of practical training to develop this pedagogical skill. The study also shows some aspects of the current state of will-be-teachers training at the Constantine the Philosopher University in Nitra based on the results of a questionnaire survey. The survey can be considered to be a kind of stimulus showing the direction where the university teacher training should head.

\section{Current State of Education Quality in Slovakia}

The outcomes of Slovak pupils at the level of primary and secondary education indicate a decrease of their level of knowledge and abilities. The situation is largely dependent on the nature of the pupils' work during the educational process and on the requirements placed on learners by teachers.

In the Slovak school environment, there is a significant effort to map the current status of student education as a prerequisite for future necessary corrections. The Ministry of Education, Science, Research and Sport of the Slovak Republic, using the services of the National Institute of Certified Measurements, has implemented a number of important international measurements of educational outcomes and educational contexts that meet the criteria of comparative educational research. The aim of the international measurements is to monitor the achievements and results of the education systems in the participating countries and their changes over time, to discover their strengths and weaknesses and to find opportunities for improvement. The level of knowledge and skills in mathematical, reading and science literacy is monitored within the framework of the Program for International Student Assessment (PISA) on a representative sample of 15-year-old pupils. The results of Slovak pupils in the last survey (2015), similarly as in the previous one in 2012, are significantly lower in all three areas than the average performance of pupils from the OECD countries. Although this drop is not statistically significant, we can see a further increase in the number of students belonging to the so called risk group (with the lowest level of knowledge). For example, reading literacy results show that, compared to 2012 ones, the average 
performance of our pupils has decreased by 10 points, which is not a significant change, but what is alarming is the increasing number of students who lack the most basic reading skills. When pointing to some of the negatives, attention needs to be paid to the ways of improving the current situation.

Learning Slovakia. Currently, a sequence of many dynamic changes can be observed through which the Slovak education system is trying to respond to social challenges, but these reactions are in many aspects rather insufficient. The Program Statement of the Government of the Slovak Republic for the years 2016-2020 has stated the task for the Ministry of Education, Science, Research and Sports of the Slovak Republic to prepare a proposal of the National Program for Development of Education and Training which would cover long-term intentions and goals in the area of improving education in the 10-year perspective. The designed material entitled Učiace sa Slovensko/Learning Slovakia is currently undergoing professional and public discussion. The starting point is the fundamental thesis which emphasizes the lifelong learning process of man as the core of his human nature and the key to a successful life (Učiace sa Slovensko: 3). Further prerequisites are the need for personal development, continuous self-education, and the development of individual potential. Education and training, oriented at the natural tendency of man to develop themselves, are of strategic importance for the Slovak society.

In the context of the main topic of our paper, it is worth highlighting the proposed new understanding of the teacher's mission, which is to develop students' wisdom, self-esteem and respect for everybody and everything, to support their responsibility and decision-making autonomy, and to stimulate their initiative, creativity, and independence. The teacher is to assist parents in educating and upbringing their children, to be an active and cooperative member of the school team, and to make the activities and efforts of all the teachers more complex and synergistic (ibidem: 93).

The aforementioned results of students in international measurements can be considered to be signals related also to the decrease in the quality of teachers' work, and that is why the proposed changes affect also this area. The first step to be taken is making the selection of candidates for teacher training programs stricter and, subsequently, increasing the requirements for the students' performance during their training. Another ambition is the change of the content of the studies curriculum; the emphasis will be put, besides professional subject studies, on pedagogy, didactics, methodology, and psychology, reflecting thus the new understanding of the teacher's role. Improving the quality of training requires a sufficient amount of teaching practice through the developed network of university training schools to ensure a more rigorous monitoring and evaluation of the effectiveness of the theoretical and practical preparation of the will-beteachers (ibidem: 96-97). 


\section{Assessment of Teachers' Competences - Improving the Quality of Their Work}

The learning and information society increases the quality requirements concerning the teacher's work; their university education should include not only the relevant subject content preparation but, above all, pedagogical and methodology preparation. The quality of teacher training and their professionalization is a challenge for education systems in a global context (OECD 2009, European Commision 2013, Psifidou 2010, Lindmeier 2011, Neuweg 2016) and at the same time it should be one of the top priorities of the national education policy. The current concept of teacher education in the Slovak Republic (Kosová 2011, Pavlov 2013) is modeled on the creation and development of key professional competences and the ambition of their interconnection with the requirements of social and professional practice. One of the responses to these requirements is also the research project Evaluation of Teachers' Competences, carried out by the team of experts from the Constantine the Philosopher University in Nitra (Slovakia). The aim of the project is to enhance the quality of the teacher's work through their assessment. At the current stage of the project life experts are working on a quality assessment model that is not executing only a control function but, above all, a stimulating one. The subject of the evaluation will be a complex of teachers' professional competences, which are already formed and developed at the level of undergraduate education and subsequently during the whole professional career of teachers.

The current situation in Slovak education shows (similarly as the research team of the project Evaluation of Teachers' Competences does) the lack of a systematic approach to the set of different teacher's professional competences and their assessment. Though professionalization (professional performance of employees) is one of the key issues discussed in the society, teaching profession is threatened by such negative trends as lowering of its social status, worsening of working conditions, deprofessionalization, questioning the role of education, which requires fundamental changes in the approach to teacher professional development. The situation required professional discourse on the topic of competences and while designing the competence profile of the Slovak teacher, the basis of it was taken from the integration model of education and its three dimensions - the pupil, the educational process, and the teacher. The set of professional competences required for the standard performance of educational activities is described in the Act No. 317/2009 on the teaching staff and other experts in the section 25 , item 3 .

Three levels of competences take into account the basic requirements for teacher performance. The competences related to students are geared towards identifying their developmental and individual traits, identifying psychological and social factors of student learning, and identifying the socio-cultural context of 
student development. The second group of competences, ensuring that the educational process happens, is the most comprehensive and diversified set of competences:

- competences related to the management of the educational process (the awareness of the content of the subjects taught, the ability to plan and design education, the ability to set learner-oriented teaching objectives, the ability to perform psycho-didactic curriculum analysis, the ability to select and implement appropriate teaching forms and methods, the ability to evaluate the progress and outcomes of student education);

- competences to create relevant conditions for education (the ability to create a positive class atmosphere and climate, the ability to create and use the material and technological facilities of the educational process);

- competences to influence student personality development (the ability to influence student's personal development, the ability to develop social skills and student attitudes, the ability to prevent and remedy socio-pathological phenomena and behavioral disorders);

- teacher-related competences (to plan and develop professional growth and self-development, the ability to identify with their professional role and school).

Despite the stated differentiation and focus on teacher's competences as a set of specific abilities, i.e. knowledge, skills and attitudes, the entire pedagogical effort is focused on the quality of the versatile preparation of the student and the basis for this is acquired at the time of pre-service training of future teachers.

\section{Pre-Service Training - Forming the Teacher's Competence to Plan the Teaching Process}

The modern school emphasizes the personality and social development of students, which is reflected not only in their good study results, but also in the set of their values. It is therefore necessary to approach the process of teaching as a complex phenomenon, including a number of factors influencing the teaching. The basic condition of the quality teaching process, good performance of teacher's work, is planning, which is one of the teacher's most important competences. The concept of the teacher's competence profile is based on a three-dimensional educational model, consisting of the following dimensions: pupil, educational process and teacher. The competence to plan education is a part of the competences associated with the management of the educational process, with creating conditions for education and influencing students' personal development (Kasáčová, Kosová 2007, Slabeciusová 2014, Suchožová 2014).

The competence to plan and design education requires specific capabilities: 
- to be aware of the issues of planning and designing the educational process (knowledge);

- to be able to plan and design the educational process in the context of the national and school curriculum and in accordance with the pupil's core competences (skills);

- to be able to reflect the real process of learning and compare it with the projected process (skills, attitudes);

- to be able to create an individualized education and training plan for pupils with special educational needs in cooperation with professionals (skill).

The pre-service training emphasizes the basics and nature of this competence. The basics include the knowledge and implementation of the combination of educational goals and student competences.

The curricular transformation of the Slovak education is based on the Act $\mathrm{N}^{\circ} 245 / 2008$ on education and training (the Education Act) which was approved by the National Council of the Slovak Republic on 22 May 2008. It sets the general objectives of education in Slovak conditions ( $\left.N^{\circ} 245 / 2008, \S 4\right)$. These are based on the need to meet student-centered requirements, which can be realized through the planning, organization and implementation of the learning process. The general objectives prioritize the content and formation area. The targeting of these objectives is carried out on the basis of specific objectives, through the organization of the learning process. These goals relate to short-time subject matter content, usually one lesson, and they include a description of the content that pupils are to absorb, the learning process, and the extent to which the planned activities are to be managed (White 2010).

Creating an educational goal requires respecting the curriculum requirements that are transformable into three basic domains, respecting the pupil's developmental and mental processes. Within the cognitive area, the following cognitive goals can be identified: remembering, understanding, application, analysis, synthesis and evaluation. Among the socio-emotional, upbringing goals we differentiate the following ones: receptivity, acceptance; responding, reaction, reflection; value, merit, value acceptance; value integration and internalization into the personality character structure. The spychomotor goals include the sensorymotor skills, habits and abilities among which we can identify: perception of activities; focus on activity; controlled activity, controlled response, imitation; automation of motor skills; complex automation of activities, expert skills; motor adaptability, adaptation to activities; creative activities, creativity (Anderson, Krathwohl 2001).

The competence to plan education is immediately compatible with the requirements that are identified with respect to the student. The student's competences are a set of demonstrable individual abilities to use the knowledge, skills, attitudes and values to achieve personality development, professional development, and to apply in both working and non-working life. The learning 
process is therefore focused not only on the theoretical acquisition of knowledge, but also on its penetration into the area of skills and attitudes of the student, who can thus solve various practical tasks and life situations. Students competences are a diverse and relatively wide complex, and in the Slovak environment the following competences are defined and required: communication and socio-interaction competences, intrapersonal and interpersonal competences, civic competences, creative problem solving competence, cultural competences, lifelong learning competence, competence to use information and communication technologies, competences in the field of mathematical and natural sciences. The acquisition of the competences characterizes a competent person capable of solving many life situations and problems. The required complex of competences is transformed into the teaching requirements expressed in thematic units of each subject in the form of a systematically achieved educational standard - content and performance (Act $\mathrm{N}^{\circ} 245 / 2008$ on education and training).

Next, the essence of planning the education, as the fundamental competence of a teacher, is analyzed.

In the context of the analyzed competence the teacher is given the role of designer and creator and so they act in several dimensions. They: a) are the designers of curriculum projects; b) develop teaching projects; c) design different teaching strategies; d) develop and create teaching and learning materials and aids; e) participate in the development of new concepts and thus innovate approaches to the teaching process; f) project learning activities and tasks for students.

During pre-service teacher training, students must become aware and understand the theoretical definition and structure of the educational planning process. The theoretical definition includes not only planning activities, but also projecting them. The reasoning for the adequacy of conceptual gripping of teacher's projecting and planning activities in educational environment is, however, not unified in Slovak pedagogical research up to the date. The differentiation may primarily be done in the context of time sessions. Designing involves the determination of the teacher's and student's work from a long-term horizon, and the concept of planning is implemented in medium and short-term planning. Designing, due to its time-consuming demands and difficulties, can be divided into long-, medium- and short-term one.

Long-term planning, the result of this activity is the design of the National Educational Program/Curriculum and the School Educational Program/Curriculum. The latter is the product of teachers and teaching staff competence to design educational activities in the context of specific school educational activities.

The National Educational Program/Curriculum is a pedagogical document at the state level, as it represents a binding national framework for a particular level of school education. The essence of the National Educational Program/Curriculum is primarily its obligatory function in the context of the unification of requirements within our school system, "it represents the first level of the two-level education. It 
is the starting document for the development of School Education Programs that represent the second level of the education model" (National Educational Program/Curriculum - Lower Secondary Education - Lower Secondary School, ISCED 2).

The components of the National Educational Program/Curriculum are defined with respect to the needs of the student at each level of education and they include: a) the general aims of education and training; b) the characteristics of each level of education; c) a graduate profile; d) education areas and cross-cutting topics; e) educational standards; f) framework curricula; g) the specificities and conditions for the education and training of pupils with special educational needs; h) organizational conditions for education and training; i) compulsory staffing; j) compulsory material, technical and space facilities and premises; k) conditions for ensuring safety and health protection in education and training.

A part of the National Educational Program/Curriculum are the framework curricula that present the mandatory minimum time allocation for each subject in each grade, with respect to the type and level of the school. The framework curricula also determine the number of available lessons for the school to decide for which subjects they will be allocated.

The School Education Program is the basic program document of the school, which must be designed in accordance with the National Educational Program/Curriculum and the currently valid legislation. Each school formulates in it its aims and focus, teaching conditions, and learning outcomes, taking primarily into consideration the specific needs of pupils, but also the real possibilities of the school and the region. The School Education Program has to respond to the regional labor market, regional development needs, and the demands of local employers.

The inseparable part of the School Education Program is the content of education, taking into account the required educational standards of different school subjects. The content of education is formulated in the school curriculum. The draft of the School Education Program is discussed during the meeting of the School Education Council and School Council, and subsequently it is approved by the school head teacher and publicized in an accessible place.

The School Curriculum is the result of a long-term design process of teaching. It is one of the basic school documents and a part of the School Education Program. It is based on the framework curriculum and it respects it. Its creation represents the process of planning and at the same time the focus (profile) of the school.

An essential part of planning the School Curriculum is identification of the school subjects with lesson allocation in accordance with the framework curriculum and the determination of subjects that will have a higher lesson allocation (use of available lessons) than it is determined within the given level of education.

The syllabus is another pedagogical document, the essence of which is the refinement of the National Educational Program/Curriculum in the educational 
standard of those subjects in which, due to the specific needs of students and school, the quality of performance is changed (achievement standard).

Regarding the compulsory subjects, the currently valid education standards for the school subjects (publicized in the National Educational Program/Curriculum) can serve as the syllabus. The lesson allocation that is set in the curriculum in order to master the content of the subject remains either unchanged, or, if necessary, it is increased, but the content of the subject is not extended.

The planning of educational activities is differentiated in terms of medium and short-term planning. A part of the medium-term design is the creation of a thematic curriculum. It implements the National Educational Program/Curriculum and its requirements in a more concrete form - educational standards and syllabi. It represents the creation of a definite form, as e.g. organizing the content of the subject matter into a set period of time. It should be noted that the result of this design is currently not considered mandatory, but, on the other hand, we draw attention to the fact that school management may require it, in particular, from novice teachers. Despite this, we also consider it necessary to deal with this form of medium-term design.

Designing the thematic curriculum is an important and challenging project activity of the teacher, which must involve a relatively long period of the subject content layout and the forms of its realization. Possible complications with its creation are related to the fact that teachers cannot have at their disposal all the relevant information associated with that design. For concrete planning, there is the lack of the information about the class, the number of pupils, their dispositions, and so on.

The thematic curriculum is a pedagogical document of the teacher, which is the result of their competence to plan the teaching process. After its approval by the methodological association, the subject committee and the school head teacher, this document becomes binding for teaching a specific subject in a particular grade and school year. Thematic planning is the core of the teacher's planning activity, and we consider the thematic plan to be a kind of an individual syllabus of the teacher.

When designing and planning the thematic curriculum, it is necessary to take into account a number of backgrounds that are part of the School Education Program/Curriculum: the syllabi that contain the educational standards in them; School Education Program/Curriculum; school concept or focus; organization of the school.

The process of creating a specific thematic curriculum takes into consideration: (1) the state of implementation of the curriculum in the previous school year; (2) the current pedagogical and organizational instructions; (3) possible innovation of educational standards in a particular subject; (4) organization of the school year; (5) teaching assumptions and students' achievements; (6) planned non-learning (out of school) activities. 
The thematic curriculum is a description of the content of the subject matter. Its recommended components are: (1) indicative timetabling and inclusion of the content into the thematic units; (2) the inclusion of specific topics implemented in each lesson; (3) identification of the educational standard - performance and content ones; (4) key competences; (5) cross-sectional topics; (6) relations between subjects; (7) methods and forms of pedagogical work with students; (8) method of evaluation (Pavlov, Dragulová 2013).

The result of the short-term design is the created model/script/plan of the lesson. Planning a lesson is a professional work that focuses on the selection of subject matter, student's learning activities, and teacher's teaching activities that aim at mastering the set of study issues by the student. The prerequisite is to create a scenario for each lesson and then, knowledge, usage and planning the teaching process at all relevant levels. The starting point is the School Educational Program/Curriculum that includes such pedagogical documents as a curriculum, a syllabus, cross-cutting topics and a thematic curriculum.

The scenario design is the result of a complicated individual thinking process of an educator that is subject to change, taking into account several factors: a) types of school and students; b) teacher's specification of the educational standard; c) concretizing and developing performance requirements; d) creative modification of the teaching and learning content; e) creative work with teaching methods and situations.

The basic components of the preparation and implementation of the school lesson: the completeness of the identification data; setting the goals; developing students' competences; the structure of a lesson, overall methodology approach and process of implementation; management of the teaching process, content and timing lay-out; the choice and application of teaching methods and forms of work from the point of view of the effectiveness and efficiency of achieving objectives; the logical presentation of the content of the subject matter in the context of didactic transformation; matched methodology approach with the age of students, differentiation with respect to students' abilities (specific and individual approach to a specific group of students); application of material teaching aids; application of cross-cutting topics and subject interdependence; corrective, control, systematization activities of the teacher/will-be-teacher; educational use of the topic; teacher's/ will-be-teacher's contact with pupils; pedagogical tact, language culture, behavior of a teacher/will-be-teacher; reflection of the prepared lesson scenario, assessment of the set program. These components of a lesson are in the center of attention in the process of pre-service teacher training.

The analyzed problem of the planning of education as a teacher's competence contains not only an explanation of its essence, but it also represents its structure. A part of pre-service training is becoming aware of its theoretical aspects, which is a prerequisite for training in the area of practical teaching skills. 


\section{Current State of the Formation of the Competence to Plan the Teaching Process}

The starting point of creating and developing professional competence to plan education at the level of undergraduate education is also finding out about the current state of will-be-teachers training.

In connection with the theoretical analysis of the different components of the planning process, we monitored the level of understanding of the importance of planning the education as one of the teacher's core competences. For this purpose we used a brief questionnaire survey. The subject of the survey was the knowledge of the students about the different levels of planning, the knowledge related to setting educational goals, and the knowledge related to students' competences, methods and forms of work as we consider these elements to be a prerequisite for practical mastering the analyzed competence. The questionnaire survey was based on auto-evaluation of respondents by means of which self-assessment of the practical aspects of the competence (the ability to plan education in line with the curricular requirements of the Slovak education system, the ability to design a lesson plan, the ability to select and implement methods supporting pupils' autonomy and activity) was carried out.

The questionnaire method represents the primary source of information for the paper. It was conducted in February and March 2017 at the Faculty of Arts, Constantine the Philosopher University in Nitra. The survey involved 120 students at the Bachelor's and Master's level of studies.

The first part of the questionnaire included also two classification questions to diversify the respondents from the point of view of their level of studies and gender. In the survey, there took part 24 students at Bachelor's level of studies, representing $20 \%$ of all the respondents, and 96 Master's level students, representing $80 \%$ of the respondents. From the point of view of the respondents' gender, 13 men took part in the survey (representing $10.83 \%$ of the total number of respondents) and 107 women (89.17\%).

The second main part of the questionnaire consisted of 11 questions, out of which 6 were closed and 5 were open ones. For the purposes of this paper, the verbal and graphical interpretation of the data from three closed questions is presented. The first of the three questions was focused on the teacher trainees' general perception of the importance of the competence to plan the educational process. The second question was aimed at finding out the opinion of the will-beteachers' about their ability to plan education in line with the national and school curriculum. The last of the three questions tested students' opinion about their ability to plan and write such lesson scenarios which would ensure achievement of the set goals and development of learners' competences. 


\section{Q1: Do you consider planning the teaching process to be one of the teacher's core competences?}

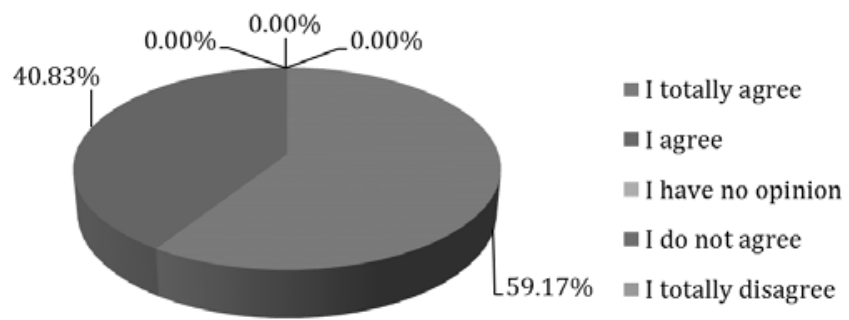

Figure 1: Assessment of the importance of the competence to plan the teaching process.

Source: authors' own elaboration.

The aim of the first question was to find out how will-be-teachers perceive the competence of planning the teaching process, whether they find it as one of the teacher's core competences (see: Figure 1). Based on the results of the survey, we can state that $59.17 \%$ of the respondents fully agree with the idea that planning the teaching process is one of the key teacher's competences, and $40.83 \%$ of the respondents endorse the claim. It was a pleasing finding that not even one of the respondents expressed the opinion that the process of planning cannot be considered to be one of the teacher's core competences. Still, having almost $41 \%$ of the respondents with the answer just "agree" should be a kind of a raised finger for teacher trainers warning them that teacher trainees are not $100 \%$ sure that the competence of planning the educational process is a "must do", which the answers to the second question show even more explicitly.

\section{Q2: Rate your ability to plan the teaching process with respect to the requirements of the national and school education program/curriculum}

Use the numbers from 1 (excellent) to 5 (insufficient, poor).

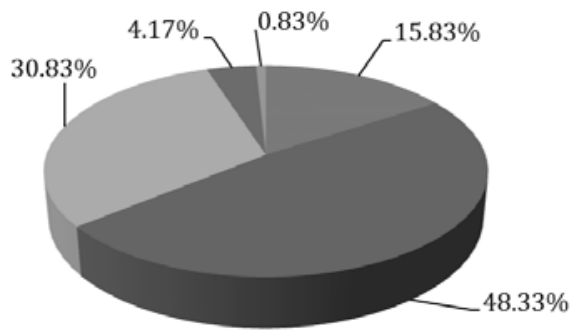

$$
\begin{aligned}
& \text { = Excellent } \\
& \text { = Very good } \\
& \text { = Good } \\
& \text { = Sufficient } \\
& \text { = Insufficient, poor }
\end{aligned}
$$

Figure 2. Assessment of the ability to plan the teaching process.

Source: authors' own elaboration. 
In the framework of the questionnaire survey it also was interesting for us to find out how will-be-teachers assess their ability to plan the teaching process with respect to the requirements of the national and school education program/curriculum. As many as $15.83 \%$ of students are convinced that their ability to plan the teaching process is extremely good and in line with the state and school requirements. Following that, $48.33 \%$ of the respondents think they are very good at planning, $30.83 \%$ evaluate their abilities as good, $4.17 \%$ consider their skills to be just sufficient, and $0.83 \%$ of the respondents think they are insufficiently prepared to handle the planning of the teaching process with respect to the stated requirements. Though it may seem that students are quite well prepared for their medium-term planning - more than half of them answered that they are excellent or very good at planning, we can see that only $15.83 \%$ of the respondents are fully self-confident. All the others have more or less hesitations about their readiness for medium-term planning, which can, for sure, be connected with low awareness about the National and School Education Program/Curriculum. Being more positive with the answers can also be connected with following the expectations of questionnaire designers - respondents stated what they had thought the designers expected them to answer. If there had been an open sub-question, for example, about how they would do that or what kind of documents they would use and where they would look for them, their confidence would, probably, have been even lower.

\section{Q3: Can you plan and write a lesson scenario (plan) in such a way that you achieve the goals of the lesson and develop students' competences?}

One of the questions of the questionnaire was aimed at finding out whether teacher trainees are able to plan and write a lesson scenario (plan) in line with the needs to achieve the set goals and requirements on the development of students' competences. As many as $31.06 \%$ of the respondents believe that their knowledge and skills (to ensure meeting the set goals and develop students' competences) in the lesson are very good. Following that, $41.67 \%$ of the respondents are not so sure, but they still think they are likely to plan a lesson in accordance with its goals and development of learners' competences. However, more than a quarter of the respondents $(27.27 \%)$ feel that they do not have enough experience to be able to plan the lesson scenario in such a way that they would fully meet the desired goals of the lesson and development of learners' competences. See Figure 3.

Though the results are quite satisfying, again we cannot fully rely on the results of the closed question as it is quite easy for the respondents to see themselves in "better light", if they are not asked for evidence or reasoning. The accompanying open sub-question would probably modify the achieved results to less positive ones. Therefore, we are considering verification of the achieved results with the following cohort of students, but this time with the improved questionnaire. 


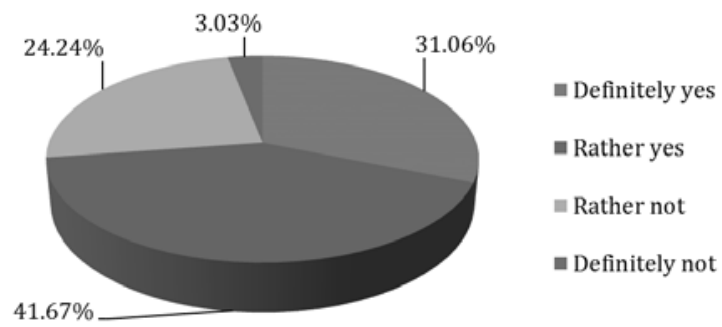

Figure 3: Assessment of the ability to plan the lesson scenario.

Source: authors' own elaboration.

Nevertheless, even the current findings of the questionnaire survey contributed to our thinking about designing a more practical training course which would support the development of the planning skills of teacher trainees.

\section{Creating a Practical Framework for the Development of the Competence to Plan the Teaching Process}

Quality undergraduate teachers' training requires, in addition to their cognitive educational needs, formation and development of their practical skills needed for their successful educational work. At the Constantine the Philosopher University in Nitra we use a number of practical training tools, implemented at a general and specific level of training. The Faculty of Education provides general education in the field of pedagogy, theory of education, psychology, didactics, and teaching methodology for teacher trainees studying at different faculties of the university. Specific training, in particular, within the courses of subject methodologies is provided by university teachers at different workplaces, and departments involved in the subject teacher training. This training, besides its theoretical focus, has the nature of training in teaching skills and it is conducted within the framework of seminar activities, oriented at practicing methodological approaches and strategies within model situations.

We want to focus our attention on an important part of university education, pedagogical practice, carried out in the real environment of primary and secondary schools. Its guarantor and organizer is the department at the Faculty of Education the Center for Lifelong Learning.

Pedagogical practice is an integral part of the complex and comprehensive training of will-be-teachers for teaching academic subjects. The content of pedagogical practice integrates all the components of the future teacher's education. It provides students with the opportunity to verify the acquired theoretical pedagogical and psychological knowledge as well as professional subject knowledge in practice and to acquire the basic practical skills necessary for 
performing the teaching profession. The role of teaching practice is: to activate and motivate students for their teaching profession, to develop their pedagogical thinking and to teach them how to implement psychological knowledge when working with various students in the classroom, to implement the acquired vocational education in school conditions, to develop the ethics of social communication of students with all the other participants in the educational process, to develop teacher trainees' skills in the area of school management.

The teaching practice is organized in three different forms. In the 3rd year of the bachelor's studies, students are obliged to pass a 10-lesson observation teaching practice during which they watch selected aspects of the educational process and record the observed phenomena in the form of specific observation sheet records. As regards the teacher's competence to plan education, the trainee teacher focuses on monitoring the work of the mentor teacher in the context of achieving the set goals and managing learners' work on the basis of the designed lesson scenario in terms of its content and methodology. They record and evaluate the suitability of the chosen methods of work from the point of view of students' activities.

The second type of teaching practice is the practice the student passes during both semesters of the first year of the master's studies, in primary and secondary schools, in the amount of 40 lessons. The trainee teachers, in addition to the observed lessons taught by the mentor teacher and their colleagues - trainee teachers, begin to teach their first lessons under the guidance of a mentor teacher. Trainee teachers deepen not only their ability to observe and analyze lessons, but increased attention is paid to developing the competence to plan a lesson and to successfully implement the lesson plan. Trainee teachers focus on designing lesson scenarios from the aspect of timing and content, effective use of teaching methods, application of didactic principles and use of teaching aids.

The last type of the teaching practice is the continuous practice held in the 2nd year of Master's studies in the amount of 60 lessons. Will-be-teachers are obliged to actively teach 30 lessons (under the supervision of a mentor teacher) of the subject in lower secondary schools and 30 lessons of it in upper secondary schools. During the continuous practice teacher trainee becomes, for the first time, a member of the school's teaching staff for a longer period of time, and though they still work under the guidance of a mentor teacher, their work becomes much more systematic, multifaceted, accountable and self-reliant. The development of the competence to plan education is intense, focused on designing and writing lesson plans in their complexity, respecting the above-described requirements.

Besides observing and teaching the lessons, the task of trainee teachers during all types of teaching practice is to collect a portfolio of documents, consisting of observation sheets, lesson plans for teaching, methodological analysis of the observed and taught lessons, evaluation and self-evaluation sheets, study materials 
and self-designed teaching aids for students and other materials used and collected during their teaching practice. An output of continuous teaching practice is also its complex analysis, part of which is self-reflection and self-evaluation. The subject of self-assessment is the emerging array of professional competences: the ability to set educational goals and organize the teaching process; the ability to select and apply appropriate methods and forms of work with regard to the efficiency of goals achievement and logical layout of the content of curriculum in the context of its didactic transformation; the ability to stratify subject matter content and timing of activities as well as apply relevantly teaching aids; the ability to develop students' competences and personalities; the ability to deal with cross-curricular topics and inter-subject and cross-curricular relations; the ability to systematize corrective, controlling and checking activities of teacher trainees and others.

An objective assessment of the quality of the acquired professional competences, both theoretical and practical, of teacher trainees is the task of mentor teachers. The content of the assessment is the quality of the will-beteachers' university training, focused on the organization and realization of their own outputs, i.e. the competence to plan the educational process connected with the competence of education management. Other assessed aspects include: the ability to educate and bring up, language culture, work discipline.

\section{Conclusion}

The results of the brief questionnaire survey conducted among the students of the Faculty of Arts, Constantine the Philosopher University in Nitra confirmed the understanding of the competence to plan education as one of the key teachers'competences also by the teacher trainees. It should be mentioned that selfassessment of teacher trainees produced relatively positive results. Future teachers are aware of both the content and performance requirements connected with the analyzed competence. They expressed quite a strong belief in their own ability to meet the target requirements, also in the view of the competences they are obliged to develop with students. Nevertheless, the achieved results are not fully reliable as closed questions encourage their respondents to mark more positive answers than they would have done if the closed question was followed by an open sub-question asking for evidence or reasoning. That is why verification of the results in a subsequent research is needed as well as it is necessary to pay adequate attention to the development of the competence of planning the teaching process during undergraduate teacher training within a well-designed structure of teaching practice, and thus gradually eliminate the current trend of the quality decrease in the education of the young generation in Slovakia. 


\section{References}

Anderson L.-W., Krathwohl D. R. (2001) A. Taxonomy for Learning, Teaching and Assessing. A Revision of Bloom's Taxonomy of Educational Objectives, New York, Longman.

European Commission (2013) Supporting Teacher Competence Development for Better LearningOutcomes, http://ec.europa.eu/dgs/education_culture/repository/ education/policy /school/doc/teachercomp_en.pdf

Kasáčová B. (2006) Kariérový systém rozvoja profesionality učitel’ov, „Pedagogické rozhl'ady", 15 (4-5): 24-27.

Kasáčová B., Kosová B. (2007) Európske trendy a slovenský prístup $k$ tvorbe učitel'ských kompetencií a spôsobilostí ako východisko k profesijným štandardom „Pedagogické rozhl'ady", 16 (3): 1-5.

Kosová B. (2011) Celoživotný rozvoj učitel’a „Pedagogické rozhl’ady”, 20 (4): 1-5.

Lindmeier A. (2011) Modeling and Measuring Knowledge and Competencies of Teachers: A threefold Domain-Specific Structure Model for Mathematics. Empiri-sche Studien zur Didaktik der Mathematik, vol. 7. Münster, Waxmann Verlag.

Neuweg G. H. (2016) Zurkompetenzorientierten Weiterentwicklung der Leistungsbeurteilung. Gehalten am 26. Jänner 2016 vor den Direktorinnen und Direktoren der humanberuflichen Schulen Österreichs in Christkindl bei Steyr.

Pavlov I. (2013) Štandardizácia profesijných kompetencií učitelov (východiská a perspektívy), Prešov, Škola plus s.r.o.

Pavlov I., Dragulová A. (2013) Kompendium na prípravu pedagogických zamestnancov na vykonanie druhej atestácie, Bratislava, MPC.

OECD (2009) Teacher Evaluation in Portugal. Assessment and Conlusions. Directorate for Education, Education and Training Policy Division, https://www.oecd.org/edu/ school/45399553

PISA (2015) Draft reading literacy framework, http://www.oecd.org/pisa/ pisaproducts/Draft\%20PISA\%202015\%20Reading\%20Framework\%20.pdf

Predanocyová L'. (2016) Rozvoj kompetencie vymedzenia a naplnenia ciel’ov edukácie in: Kompetencie učitel'ov a ich overovanie (so zameraním na učitel'ov občianskej náuky), Nitra, UKF: 19-32.

Slabeciusová E. (2014) Kritéria hodnotenia pedagogických zamestnancov, Bratislava, Metodicko-pedagogické centrum. 
Suchožová E. (2014) Rozvíjanie a hodnotenie klúčových kompetencií v edukačnom procese, Bratislava, Metodicko-pedagogické centrum.

Šnídlová M. (2011) Tvorba profesijných štandardov a nástrojov hodnotenia rozvoja profesijných kompetencií, „Pedagogické rozhl’ady”, 20 (3): 2-3.

Učiace sa Slovensko. Národný program rozvoja výchovy a vzdelávania, Ministerstvo školstva, vedy, výskumu a športu Slovenskej republiky, 226 s., www.minedu.sk

Vališová A., Kasíková H. (2011), Pedagogika pro učitele,Praha: Grada Publishing, a.s. Výsledky slovenských 15-ročných žiakov sú podl'a medzinárodnej štúdie PISA 2015 pod priemerom krajín OECD, www.minedu.sk

White J. (2010) The Aims of Education Restated, „International Library of the Philosophy of Education", 22.

Zákon č. 245/2008 Z. z. o výchove a vzdelávaní (školský zákon) a o zmene a doplnení niektorých zákonov schválenom NR SR 22. 5. 2008.

Zákon z 9. decembra 2014, ktorým sa mení a doplńa zákon č. 245/2008 Z. z. o výchove a vzdelávaní (školský zákon) a o zmene a doplnení niektorých zákonov v znení neskorších predpisov, ktorým sa menia a dopín̆ajú niektoré zákony. 